\title{
ТЕХНОЛОГІЇ ФОРМУВАННЯ ІНДИВІДУАЛЬНОЇ ТРАЄКТОРІЇ НАВЧАННЯ В ДИСТАНЦІЙНІЙ ОСВІТІ ЛІКАРІВ І ПРОВІЗОРІВ
}

\author{
О. П. Мінцер, А. Г. Габович, С. П. Кошова \\ Національна медична академія післядипломної освіти імені П. Л. Шупика
}

\begin{abstract}
Розглянуто питання формування індивідуальної освітньої траєкторії в системі післядипломного навчання лікарів і провізорів. Підкреслюється, що, не зважаючи на подальші процеси відкриття університетської освіти, створення платорорм дистанційного передавання знань, фрормування індивідуального освітнього плану не здійснюється. Відсутнє й математичне оцінювання оптимізації навчання. Важливим стає визначення основних принципів формування індивідуальної освітньої траєкторії. Зроблено висновки про те, що побудову індивідуальної освітньої траєкторії лікарів і провізорів слід завершити на етапі бакалаврату. Підкреслено також, що портороліо як основний документ лікаря повинен містити технологічну карту проходження освіти з обов'язковим включенням у процес навчання навиків, пов'язаних із пацієнтоцентрованим підходом, принципам комунікації і підвищеним умістом поведінкових і соціальних наук.
\end{abstract}

Ключові слова: індивідуальна траєкторія навчання, портфроліо лікаря, технологічна карта навчання, особистісно-орієнтована освіта.

\section{TECHNOLOGIES FOR THE FORMATION OF INDIVIDUAL TRAINING IN DISTANCE EDUCATION OF DOCTORS AND PHARMACISTS}

\author{
O. P. Mintser, A. G. Gabovych, S. P. Koshova \\ Shupyk National Medical Academy of Postgraduate Education
}

\begin{abstract}
Background. The questions of formation of individual educational trajectory in the system of postgraduate training of doctors and pharmacists are considered. It is emphasized that in spite of the further processes of university education opening, creation of remote knowledge transfer platforms, formation of an individual educational plan is not carried out. There are no mathematical estimates for learning optimization.

Materials and methods. Results. It becomes important to determine the basic principles of forming an individual educational trajectory. It is concluded that the construction of an individual educational trajectory of doctors and physicians should be completed at the bachelor's stage.

Conclusion. It is emphasized that the portfolio, as the primary document of the doctor, should contain a technological map of education, with mandatory inclusion in the process of teaching skills related to patient-centered approach, communication principles and increased content of behavioral and social sciences.
\end{abstract}

Key words: individual educational trajectory, doctor's portfolio, technology map of training, personality-oriented education.

\section{ТЕХНОЛОГИИ ФОРМИРОВАНИЯ ИНДИВИДУАЛЬНОЙ ТРАЕКТОРИИ ОБУЧЕНИЯ В ДИСТАНЦИОННОМ ОБРАЗОВАНИИ ВРАЧЕЙ И ПРОВИЗОРОВ}

\author{
О. П. Минцер, А. Г. Габович, С. П. Кошевая
}

Национальная медицинская академия последипломного образования имени П. Л. Шупика

\begin{abstract}
Рассмотрены вопросы формирования индивидуальной образовательной траектории в системе последипломного обучения врачей и провизоров. Подчеркивается, что, несмотря на дальнейшие процессы открытия университетского образования, создание платорорм дистанционной передачи знаний, формирование индивидуального образовательного плана не осуществляется. Отсутствуют и математические оценки оптимизации обучения. Важным становится определение основных принципов формирования индивидуальной образовательной траектории. Сделаны выводы о том, что построение индивидуальной образовательной траектории врачей и провизоров следует завершить на этапе бакалаврата. Подчеркнуто также, что портфолио как основной документ врача должен содержать технологическую карту прохождения образования с обязательным включением в процесс обучения навыков, связанных с пациентоцентрованим подходом, принципами коммуникации и повышенным содержанием поведенческих и социальных наук.
\end{abstract}

Ключевые слова: индивидуальная образовательная траектория, портфолио врача, технологическая карта обучения, личностно-ориентированное образование. 
Вступ. Останній час ознаменувався докорінними змінами вищої освіти $[1,2,3,4]$. Обумовлено й нові підходи в оцінюванні якості освіти, що пов'язані 3 характеристиками компетентностей $[5,6]$. У той же час, поява певної кількості технологій передавання знань із особливою гостротою поставила питання щодо можливості отримання системної освіти. Дійсно, навчання за допомогою віртуальних семінарів, платформного навчання, дистанційних методів хоча й надає можливість суб'єкту навчання отримати певні порції знань чи компетентностей, але залишає без відповіді питання щодо системності освіти, формування мотивації, виявлення «прогалин» у знаннях. Подальша лібералізація процесів отримання знань може призвести до суттєвого зниження кількості особистостей, що неодмінно негативно позначиться на якості професійної діяльності [7]. Безумовно, в першу чергу, слід назвати галузь охорони здоров'я. Здавалося, вочевидь, у медичній освіті, особливо в післядипломній, формування індивідуального освітнього плану $є$ однією з не численних можливостей професійного зростання. Проте, в дійсності дослідження подібного плану поодинокі [8].

Мета роботи: визначення основних принципів формування індивідуальної траєкторії навчання.

Результати та їх обговорення. Будемо називати індивідуальною траєкторією навчання лікаря систему нарощування особистісної професійної сформованості. Вона включає як ключові, так і професійні компетентності з орієнтацією на мотивацію, потреби у професійному зростанні, фізичні, технічні та фінансові можливості, постійну самоосвіту та саморозвиток. Специфіку компетентністного підходу складають професійно орієнтовані технології, умови та особливості навчального контенту.

Інструменти прецизійної медицини дали більш глибоке розуміння клітинних і молекулярних детермінант індивідуальної унікальності. Тому вкрай важливо здійснити перехід від знеособленого надання медичної допомоги до нових моделей надання медичних послуг, що $є$ персоналізованими, контекстуалізованими та інтегрованими. Але для забезпечення особистісно-орієнтованої охорони здоров'я в рамках системи охорони здоров'я потрібна особистісно-орієнтована освіта та професійна підготовка. Перш за все, з трансформацією сучасної медицини змінюються вимоги й очікування щодо навиків, якими повинні оволодіти лікарі, таких як більш глибоке мислення та критичний аналіз під час непередбачених і незнайомих ситуацій або в ході наукових досліджень. Останнє потребує гарного розуміння медичних знань, а також здатності застосовувати ці медичні навики та знання до різних сценаріїв, що найкраще досягається за допомогою безперервного професійного розвитку. Відповідно, формування індивідуальної траєкторії навчання, перш за все, має проходити на етапі бакалаврату, коли більшість студентів починають використовувати глибокий і стратегічний підхід до навчання, а по-друге, повинна мати характеристику варіативності. Фіксація індивідуальної траєкторії навчання має проводитися в портфоліо (як в основному ідентифікаційному документі лікаря) у форматі спеціалізованої технологічної карти.

Слід також підкреслити, що навчання лікарів на етапі післядипломної освіти навикам, пов'язаним із пацієнт-центрованим підходом, принципами комунікації, підвищеною кількістю поведінкових і соціальних наук в індивідуальній програмі освіти, так само важливо, як навчання молекулярно-генетичним основам здоров'я та хвороби.

Отже, представляється своєчасним подальше вивчення можливостей втручання та змінення викладачами теоретичних і клінічних методів навчання лікарів для його оптимізації на основі персоналізації методів навчання.

Висновки. 1. Рекомендовано побудову індивідуальної траєкторії навчання завершити на етапі бакалаврату.

2. Портфоліо як основний документ лікаря повинно містити технологічну карту проходження освіти з обов'язковим включенням у процес навчання навиків, пов'язаних із пацієнт-центрованим підходом, принципами комунікації та підвищеним вмістом поведінкових і соціальних наук. 


\section{Література.}

1. Закон України «Про вищу освіту» від 01.07.2014 № 1556-VII (у редакції від 18.12.2019).

2. Канаев Н. М. Глобализация и высшее образование. Взгляд из ЮНЕСКО / Канаев Н. М. // Философия образования. — 2005. — № 1 (12). - С. 26-31.

3. Клепко С. Ф. Інтегративна освіта і поліформізм знання / Клепко С. Ф. - К. - Полтава. - Харків, 1998. - 360 с.

4. К вопросу о развитии высшего образования в контексте глобализации / Ковалева О. В., Мазуркевич Л. А. - Донецьк: ДонНТУ, 2009. С. 115-122. — Режим доступу: http://ea.donntu.edu. ua/bitstream/123456789/10838/4/kovaleva.pdf.

5. Овчарук О. В. Компетентнісний підхід у сучасній освіті: Світовий досвід та українські перспективи: Бібліотека з освітньої політики / Овчарук О. В. K.: KIC, 2004. - 112 c.

6. Равен Дж. Компетентность в современном обществе: выявление, развитие и реализация / Равен Дж. М.: Когито-Центр, 2002. - 396 с.

7. Miles J. E. AsbridgeThe European Society for Person Centered Healthcare (ESPCH) — raising the bar of health care quality in the Century of the Patient / Miles J. E. // J Eval Clin Pract. — 2014. — № 20. — P. 729-733.

8. Towards a person-centered medical education: challenges and imperatives / Miles A., Asbridge J., Caballero F. // Educación Médica. — 2015. — Vol. 16, Iss. 1. — P. 25-33.

\section{References.}

1. Zakon Ukrayini «Pro vishu osvitu» [The Law of Ukraine «On Higher Education»] vid 01.07.2014 № 1556-VII (redakciya vid 18.12.2019). [In Ukrainian].
2. Kanaev, N. M. (2005). Globalizaciya i vysshee obrazovanie. Vzglyad iz UNESKO [ Globalization and higher education. A view from UNESCO]. Filosofiya obrazovaniya (Philosophy of Education), 1 (12), 26-31. [In Russian].

3. Klepko, S. F. (1998). Integrativna osvita i poliformizm znannya. [Integrative education and the polyformism of knowledge]. Kyiv - Poltava - Harkiv, 360. [In Ukrainian].

4. Kovaleva, O. V., Mazurkevich, L. A. (2009). K voprosu o razvitii vysshego obrazovaniya v kontekste globalizacii. [On the issue of higher education development in the context of globalization]. Donetsk: DonNTU, 115-122. URL: http://ea.donntu.edu.ua/ bitstream/123456789/10838/4/kovaleva.pdf. [in Russian].

5. Ovcharuk, O. V. (2004). Kompetentnisnij pidhid u suchasnij osviti: Svitovij dosvid ta ukrayinski perspektivi. [Approach in Contemporary Education: World Experience and Ukrainian Perspectives: Biblioteka z osvitnoyi politiki]. Kyiv: KIS, 112. [In Ukrainian].

6. Raven, Dz. (2002). Kompetentnost v sovremennom obshestve: vyyavlenie, razvitie i realizaciya. [Competence in modern society: identification, development and realization]. Moscow: Cogito Center, 396. [In Russian].

7. Miles, A. , Asbridge, J. E. (2014). The European Society for Person Centered Healthcare (ESPCH) — raising the bar of health care quality in the Century of the Patient. J Eval Clin Pract., 20, 729-733.

8. Miles, A., Asbridge, J. E., Caballero, F. (2015). Towards a person-centered medical education: challenges and imperatives. Educación Médica, 16 (1), 25-33. 